\title{
МОРФОМЕТРИЧНИЙ АНАЛІЗ КЛІТИННО ЛАНКИ МІСЦЕВОГО ІМУНІТЕТУ ПРИ ГІПЕРПЛАСТИЧНИХ ПРОЦЕСАХ ЕНДОМЕТРІЯ У ЖІНОК ПРЕ- ТА МЕНОПАУЗАЛЬНОГО ВІКУ
}

\author{
ФП. Р. Сельський, А. Ф. Слива, П. О. Ваврух \\ ДВНЗ «Тернопільський державний медичний університетімені І. Я. Горбачевського МОЗ України»
}

РЕЗЮМЕ. Проведено гістологічне та морфометричне дослідження 44 пацієнток з гіперпластичними процесами ендометрія. У більшості хворих спостерігали порушення місцевого клітинного імунітету. Виявлена залежність імунних порушень від ступеня розвитку гіперпластичних процесів. На основі проведених досліджень можна зробити висновок про суптєвий вплив імунних чинників на прогрес даного захворювання.

КЛЮЧОВІ СЛОВА: гіперпластичні процеси ендометрія, клітинний імунітет, клітинний інфільтрат.

Вступ. Гіперпластичні процеси ендометрія (ГПЕ) є найпоширенішою патологією слизово матки. У структурі гінекологічно патологі вони складають від 10 до 50 \% [3, 5]. Найчастіше ГПЕ діагностують у жінок віком 45-55 років, при цьому - до $50 \%$ в пізньому репродуктивному та перименопаузальному періодах [10]. Своєчасна діагностика та лікування ГПЕ $\epsilon$ важливою медико-соціальною проблемою, зумовленою не тільки високою частотою розвитку метрорагій і ендометритів, а й ризиком малігнізаці , оскільки в 30-70 \% випадків рак ендометрія в пери- і постменопаузі розвивається на тлі гіперпластичних процесів [4]. Поряд із дисгормональними впливами, які часто супроводжують перименопаузальний вік, в розвитку ГПЕ важливе значення мають імунні порушення.

В останні роки в оцінці морфофункціонального стану ендометрія при ГПЕ велика увага приділяється показникам місцевого імунітету. Дослідження більшості авторів, проведені в цьому напрямку [5, 7, 9], свідчать про зміни клітинного імунітету при даній патологі, а саме: переважання в клітинному інфільтраті строми лімфоцитів та плазмоцитів. Проте залишається не до кінця з'ясованим характер порушень клітинно ланки місцевого імунітету при різних видах ГПЕ [5].

Мета дослідження. Встановити склад та щільність розміщення клітинного інфільтрату при різних видах гіперпластичних процесів ендометрія.

Методи дослідження. Обстежено 44 жінки віком від 39 до 53 років з ГПЕ, які перебували на обстеженні в гінекологічному відділенні «Комунально установи Тернопільська клінічна міська лікарня № 2", м. Тернопіль. Патогістологічний діагноз верифікований клінічно та патогістологічно згідно з класифікацією гіперпластичних процесів ендометрія ВООЗ 1994 р. [9]. Контрольну групу становили 12 соматично здорових жінок віком $(45,5 \pm 0,7)$ року, діагностичне вишкрібання у яких проводилось з приводу дисфункціональних маткових кровотеч. Матеріал, отриманий шляхом роздільного діагностичного вишкрібання, фіксува- ли протягом одніє доби в $10 \%$ нейтральному формаліні та проводили через спирти, заливали в парафін для приготування серійних зрізів. Гістологічні зрізи товщиною 5 мкм фарбували гематоксиліном і еозином [1]. Вивчення препаратів здійснювали за допомогою світлового мікроскопа МБИ-15.

Розподіл клітинного інфільтрату ендометрія досліджували в 10 полях зору [1, 6, 9]. Аналіз морфологічного зображення проводили з використанням комп'ютерно програми IBAS-2000 фірми "OPTON" (Німеччина).

Математичний аналіз даних проведений за допомогою методів варіаційного, кореляційного аналізу з використанням стандартного пакета прикладних програм Microsoft Excel.

Результати й обговорення. Відповідно до патогістологічного висновку, матеріал поділявся таким чином: проста гіперплазія ендометрія (ПГЕ) 1 -а група (50 \%) та комплексна гіперплазія ендометрію (КГЕ) - 2-а група (50\%). Вік пацієнток 3 простою гіперплазією складав $(46 \pm 1,4)$ років, а 3 комплексною гіперплазією - $(48 \pm 0,5)$ років. Діагноз просто гіперплазі ендометрія встановлювали на підставі виявлення виражено проліфераці залозистих і стромальних компонентів ендометрія $[5,6]$. При складній гіперплазі ми спостерігали скупчення залоз ендометрія, які прилягали спина до спини та варіювали за формою і розмірами, але не мали ознак клітинно атипі.

Аналіз клітинного складу інфільтрату матки у жінок 1- групи показав, що за сво м складом він був однотипним у всіх випадках і представляв собою скупчення лімфоцитів із наявністю поодиноких макрофагів та плазмоцитів. Клітинний інфільтрат мав дифузний характер. Щільність інфільтрату в стромі ендометрія становила $(43 \pm 1,5)$ клітин в одному полі зору.

При КГЕ (2-а група) в клітинному інфільтраті спостерігалось переважання лімфоцитів. В стромі ендометрія виявлено дифузний інфільтрат, проте мало місце і осередкове розміщення імуноком- 
Оеляди літератури, ориаінальні дослідження, поеляд на проблему

петентних клітин. Щільність клітинного інфільтрату становила $(72 \pm 2,4)$ клітин в полі зору та була значно більшою, ніж при ПГЕ $(p<0,001)$.
Розподіл клітинного інфільтрату в стромі ендометрія при різних видах гіперпластичних процесів наведений у таблиці 1.

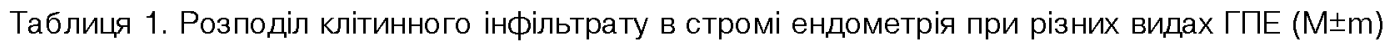

\begin{tabular}{|c|c|}
\hline Група & Кількість клітин в одному полі зору \\
\hline Контрольна група & $35,0 \pm 2,6$ \\
\hline Проста гіперплазія ендометрія & $43,0 \pm 1,5 *$ \\
\hline Комплексна гіперплазія ендометрія & $72,0 \pm 2,4 * *$ \\
\hline
\end{tabular}

Примітка. * - p<0,05 порівняно з контрольною групою, ** - p<0,001 порівняно з простою гіперплазією ендометрія.

Висновки. 1. Виявлені зміни свідчать про важливу роль порушень клітинного імунітету на місцевому рівні у розвитку гіперпластичних процесів ендометрія.

2. Результати аналізу клітинного складу інфільтрату тканин показали, що за сво м складом він був однотипним при всіх видах дано патологі i представляв собою скупчення лімфоцитів із наявністю поодиноких плазмоцитів та макрофагів з переважно дифузним х розміщенням.

\section{ЛІТЕРАТУРА}

1. Автандилов Г. Г. Основы количественной патологической анатомии / Г. Г. Автандилов. - М. : Медицина, 2002. - 240 c.

2. Березький О. М. Інформаційно-аналітична система дослідження та діагностування пухлинних клітин на основі аналізу хзображень /О.М.Березький, Ю. М. Батько, Г. М. Мельник // Вісник Хмельницького національного університету. - 2008. - Т. 1, № 4. - С. 33-42.

3. Дубровина С. О. Патогенетические аспекты гиперпластических процессов в эндометрии у женщин с метаболическим синдромом / С. О. Дубровина // Российский вестник акушера-гинеколога. - 2008. - № 3. C. $41-44$.

4. Думановская М. Р. Вероятность неопластической трансформации при различных типах гиперплазии эндометрия / М. Р. Дурмановская, Г. Е. Чернуха, О. В. Бурменская // Акушерство и гинекология. - 2013. - № 8. C. $56-62$.

5. Коломиец Л. А. Клинические особенности гиперпластических процессов эндометрия и рака эндометрия в различные возрастные периоды / Л. А. Коломиец,
3. Найбільша щільність інфільтрату спостерігалась при комплексній гіперплазі ендометрія з найбільшою структурною перебудовою, що вказує на важливу роль порушень місцевого клітинного імунітету.

Перспективи подальших досліджень. Виявлені зміни свідчать, що осередкові порушення клітинного імунітету мають суттєве значення в патогенезі гіперпластичних процесів ендометрія та розкривають перспективи покращення морфологічно верифікаці його патологічних процесів.

А. Б. Мунтян, Н. В. Бочкарева // Сибирский онколо гический журнал. - 2007. - № 2. - С. 133-134.

6. Кузнецов И. В. Гиперпластические процессы эндометрия. - М. : Медицина, 2009. - 48 с.

7. Лысенко О. Н. Показатели клеточного иммунитета у больных железистой и аденоматозной гиперплазией эндометрия в перименопаузальном периоде / О. Н. Лысенко, Н. В. Стрижова, Ж. Л. Холодова // Бюллетень экспериментальной биологии и медицины. - 2003. T. 135, № 1. - С. 90-94.

8. Сельський П. Р. Стан клітинно та гуморально ланок імунітету у хворих на ендоцервікоз / П. Р. Сельський // Матеріали VI Міжнародного медичного конгресу студентів та молодих учених. - Тернопіль, 2002. - С. 308.

9. Хмельницкий О. К. Цитологическая и гистологическая диагностика заболеваний шейки и тела матки / О. К. Хмельницкий. - Санкт-Петербург, 2000. - 336 с.

10. Significance of hormone receptor status and tumor vessels in normal, hyperplastic and neoplastic endometrium / O. Nunobiki, E. Taniguchi, A. Ishii [et al.] // Pathol. Int. 2003. - Vol. 53, № 12. - P. 846-852.

\title{
MORPHOMETRIC ANALYSIS OF CELLULAR LINK OF LOCAL IMMUNITY IN WOMEN OF PREMENOPAUSAL AND MENOPAUSAL AGE WITH ENDOMETRIAL HYPERPLASIA
}

\author{
๑P. R. Selskyy, A. F. Slyva, P. O. Vavrukh \\ SHEI «Ternopil State Medical Universiti by I. Ya. Horbachevsky of MPH of Ukraine»
}

SUMMARY. There were performed histological and morphometric study of 31 patients with endometrial hyperplasia. In the majority of patients were observed violation of local cellular immunity. It was found dependence of immune disorders on the degree of hyperplastic processes. Based on the research we can conclude significant influence of immune factors on the progress of the disease.

KEY WORDS: endometrial hyperplasia, cellular immunity, cellular infiltration. 